\title{
KAITAN PEMBELAJARAN BERBASIS MASALAH DENGAN KEMAMPUAN SELF-EFFICACY SISWA
}

Oleh:

\author{
Reflina* \\ *Dosen Tetap Jurusan Pendidikan Matematika FITK UIN-SU Medan \\ *Jl. Williem Iskandar Pasar V Medan Estate \\ e-mail: reflina74@gmail.com
}

\begin{abstract}
:
Self-Efficacy is a positive attitude that an individual can make himself able to develop a positive assessment both to themselves and to the environment / situation. According to Bandura's social cognitive theory, self-efficacy beliefs influence people's choices in making and carrying out the actions they are pursuing. Self-efficacy measurement of a person based on three dimensions, namely: magnitute, Strength, Generality. Problembased learning is a learning that demands students' mental activity optimally in learning critical thinking, problem-solving skills, and gaining knowledge about the essence of the subject matter in understanding a student's concept or concept, principles and mathematical skills in the form of ill-stucture or open-ended through stimulus.
\end{abstract}

Keywords:

Problem-Based Learning, Self-Efficacy

\section{A. Self-efficacy}

1. Pengertian Self-efficacy

Self-efficacy terdiri dari kata "self" yang dapat diartikan sebagai unsur struktur kepribadian, dan "efficacy" yang memiliki makna penilaian diri, apakah dapat melakukan tindakan yang baik atau buruk, tepat atau salah, bias atau tidak bisa mengerjakan sesuatu. Dari berbagai pendapat para ahli, self-efficacy pada prakteknya sinonim dengan "kepercayaan diri"

Kepercayaan diri adalah sikap positif seorang individu yang dapat membuat dirinya mampu untuk mengembangkan penilaian positif baik terhadap diri sendiri maupun terhadap lingkungan/situasi yang dihadapinya. Untuk menumbuhkan rasa percaya diri yang proporsional maka individu harus memulainya dari dalam diri sendiri. Hal ini sangat penting mengingat bahwa hanya individu yang bersangkutan yang dapat mengatasi rasa kurang percaya diri yang sedang dialaminya.

Teori self-efficacy didasarkan atas teori sosial-kognitif Bandura yang mendalilkan bahwa prestasi atau kinerja seseorang tergantung kepada interaksi antara tingkah laku, faktor pribadi (misalnya: pemikiran, keyakinan) dan kondisi lingkungan seseorang (Sudrajat dalam Widyastuti, 2010: 31).

Bandura mendefinisikan self-efficacy sebagai judgement seseorang atas kemampuannya untuk merencanakan dan melaksanakan tindakan yang mengarah 
pada pencapaian tujuan tertentu. Bandura menggunakan istilah self-efficacy mengacu pada keyakinan (beliefs) tentang kemampuan seseorang untuk mengorganisasikan dan melaksanakan tindakan untuk pencapaian hasil. Dengan kata lain, self-efficacy adalah keyakinan penilaian diri berkenaan dengan kompetensi seseorang untuk sukses dalam tugas-tugasnya. Menurut Bandura, keyakinan self-efficacy merupakan faktor kunci sumber tindakan manusia (human egency), "apa yang orang pikirkan, percaya, dan rasakan mempengaruhi bagaimana mereka bertindak".

Di samping itu, keyakinan efficacy juga mempengaruhi cara atas pilihan tindakan seseorang, seberapa banyak upaya yang mereka lakukan, seberapa lama mereka akan tekun dalam menghadapi rintangan dan kegagalan, seberapa kuat ketahanan mereka menghadapi kemalangan, seberapa jernih pikiran mereka merupakan rintangan diri atau bantuan diri, seberapa banyak tekanan dan kegundahan pengalaman mereka dalam meniru (copying) tuntunan lingkungan, dan seberapa tinggi tingkat pemenuhan yang mereka wujudkan.

Menurut teori kognitif sosial Bandura, keyakinan self-efficacy mempengaruhi pilihan orang dalam membuat dan menjalankan tindakan yang mereka kejar. Individu cenderung berkonsentrasi dalam tugas-tugas yang mereka rasakan mampu dan percaya dapat menyelesaikannya serta menghindari tugastugas yang tidak dapat mereka kerjakan. Keyakinan efficacy juga membantu menentukan sejauh mana usaha yang akan dikerahkan orang dalam suatu aktivitas, seberapa lama mereka akan gigih ketika menghadapi rintangan, dan seberapa ulet mereka akan menghadapi situasi yang tidak cocok. Keyakinan efficacy juga mempengaruhi sejumlah stress dan pengalaman kecemasan individu seperti ketika mereka menyibukkan diri dalam suatu aktifitas.

\section{Karakteristik Self-Efficacy}

Maddux (Sudrajat, 2008) menguraikan beberapa makna dan karakteristik dari self-efficacy, yaitu:

a. Self-efficacy merupakan keterampilan yang berkenaan dengan apa yang diyakini atau keyakinan yang dimiliki seseorang untuk melakukan atau menyelesaikan sesuatu dengan keterampilan yang dimilikinya dalam situasi atau kondisi tertentu. Biasanya terungkap dari pernyataan "Saya yakin dapat mengerjakannya".

b. Self-efficacy bukan menggambarkan tentang motif, dorongan, atau kebutuhan lain yang dikontrol.

c. Self-efficacy ialah keyakinan seseorang tentang kemampuannya dalam mengkoordinir, mengerahkan keterampilan dan kemampuan dalam mengubah serta menghadapi situasi yang penuh dengan tantangan.

d. Self-efficacy adalah keyakinan seseorang terhadap apa yang mampu dilakukannya.

e. Proporsi self-efficacy dalam domain harga diri (self-esteem) secara langsung berperan penting dalam menempatkan diri seseorang untuk menampilkan prilaku produktif.

f. Self-efficacy diidentifikasi dan diukur bukan sebagai suatu ciri tetapi sebagai keyakinan tentang berbagai keteampilan dan kemampuan 
mencapai tujuan yang diharapkan, dalam domain dan kondisi atau keadaan khusus.

g. Self-efficacy berkembang sepanjang waktu dan diperoleh melalui suatu pengalaman. Perkembangannya dimulai pada masa bayi dan berlanjut sepanjang hayat.

h. Self-efficacy secara sederhana menggambarkan keyakinan seseorang untuk menampilkan perilaku produktif.

Menurut Bandura (Dewanto, 2007), self-efficacy yang merupakan konstruksi sentral dalam teori kognitif sosial yang dimiliki seseorang akan:

a. Mempengaruhi pengambilan keputusannya, dan mempengaruhi tindakan yang akan dilakukannya. Seseorang cenderung akan menjalankan sesuatu apabila ia merasa kompeten dan percaya diri, dan akan menghindariya bila tidak.

b. Membantu seberapa jauh upaya untuk bertindak dalam suatu aktivitas, berapa lama ia bertahan apabila mendapat masalah, dan seberapa fleksibel dalam suatu situasi yang kurang menguntungkan baginya. Makin besar self-efficacy seseorang, makin besar upaya, ketekunan, dan fleksibilitasnya.

c. Mempengaruhi pola piker dan reaksi emosionalnya. Seseorang dengan self-efficacy yang rendah mudah menyerah dalam menghadapi masalah, cenderung menjadi stres, depresi, dan mempunyai suatu visi yang sempit tentang apa yang terbaik untuk menyelesaikan masalah itu. Sedangkan self-efficacy yang tinggi, akan membantu seseorang dalam menciptakan suatu perasaan tenang dalam menghadapi masalah atau aktivitas yang sukar.

Dari pengaruh-pengaruh ini, self-efficacy berperan dalam tingkatan pencapaian yang akan diperoleh, sehingga Bandura (Parajes, 2002) berpendapat bahwa self-efficacy menyentuh hamper semua aspek kehidupan manusia, apakah berpikir secara produktif, secara optimis atau optimis, bagaimana mereka memotivasi diri, kerawanan akan stres dan depresi, serta keputusan yang dipilih.

\section{Sumber-Sumber Self-Efficacy}

Menurut Bandura (Sudrajat, 2008), self-efficacy secara kontinu turut berkembang sepanjang hayat serta mengintegrasikan informasi dari empat sumber utama sebagai berikut.

a. Pengalaman Keberhasilan (Performance Experiences)

Pengalaman keberhasilan merupakan prestasi yang pernah dicapai pada masa yang telah lalu. Sebagai sumber, pengalaman keberhasilan menjadi pengubah self-efficacy yang paling kuat engaruhnya karena prestasi/ kegagalan pengalaman yang lalu akan mempengaruhi self-efficacy seseorang untuk pengalaman yang serupa kelak. Persepsi atas kegagalan atau keberhasilan atas sesuatu pada umumnya akan melemahkan atau 
meningkatkan self-efficacy seseorang. Semakinseseorang mengalami keberhasilan dalam hidupnya maka makin tinggi taraf self-efficacy nya, dan sebaliknya.

b. Pengalaman Perumpamaan (Vicarious Experiences)

Self-efficacy juga dipengaruhi oleh observasi seseorang terhadap perilaku orang lain. Hal ini didasarkan pada teori belajar observasional yang menyatakan bahwa seseorang dapat belajar secara terus-menerus dengan mengamati tingkah laku orang lain. Ia menggunakan informasi hasil observasinya untuk membentuk harapan tentang perilaku dan konsekuensinya, terutama tergantung pada tingkat keyakinan mana dirinya mempunyai keamanan dengan orang yang diobsevasinya. Pengalaman orang lain ini biasanya diperoleh melalui model di dalam interaksi sosial. Pengalaman ini secara umum pengaruhnya lebih lemah terhadap selfefficacy dibandingkan dengan mengalaminya sendiri. Model pengalaman orang ain ini sangatlah berpengaruh apabila ia mendapat situasi yang serupa dan kurang memiliki pengalaman dalam pengalaman tersebut.

c. Persuasi Verbal

Persuasi verbal merupakan pendekatan yang dilakukan dengan perkataan untuk meyakini seseorag bahwa ia memiliki kemampuan atau tidak untuk melakukan sesuatu. Sumber ini memberikan dampak terbatas pada selfefficacy, tetapi pada kondisi yang tepat persuasi dari orang lain dapat mempengaruhi self-efficacy. Kondisi yang tepat itu adalah rasa percaya kepada pemberi persuasi, kemahiran dari pemberi persuasi, dan sifat realistic dari apa yang dipersuasikan.

d. Keadaan atau Kondisi Fisiologi dan Emosi

Keadaan fisik dan emosional berpengaruh terhadap self-efficacy, biasanya kegagalan atau keberhasilan akan memunculkan reaksi fisiologi, baik yang menyenagkan atau sebaliknya. Reaksi fisiologis yang tidak menyenagkan dapat menyebabkan seseorang meragukan kemampuannya dalam menyelesaikan sesuatu. Emosi yang kuat, takut, cemas, stress dapat mengurangi self-efficacy seseorang. Namun, peningkatan (yang tidak berlebihan) dapat meningkatkan self-efficacy.

\section{Fungsi dan Pengaruh Self-efficacy}

Menurut Bandura persepsi diri atas efficacy yang berlangsung dalam diri individu keberadaannya merupakan fungsi yang menentukan bagaimana cara individu bertindak, memberikan pola-pola pemikiran dan reaksi emosi. Secara lebih rinci pengaruh dan fungsi self-efficacy tersebut adalah sebagai berikut:

a. Pemilihan Perilaku

Bandura menjelaskan bahwa dalam kehidupan sehari-hari orang harus membuat keputusan untuk mencoba berbagai tindakan dan seberapa lama menghadapi kesulitan-kesulitan. Teori belajar sosial menyatakan bahwa permulaan dan pengaturan transaksi dengan lingkungan sebagian ditentukan oleh penilaian self-efficacy, orang cenderung menghindari situasi-situasi yang diyakini melampaui kemampuannya, akan tetapi dengan penuh keyakinan, mereka akan mengambil dan melakukan 
kegiatan yang diperkirakan dapat diatasinya. Self-efficacy yang mendorong individu untuk terlibat aktif dalam kegiatan, akan mendorong perkembanan kompetensi.

b. Besar Upaya dan Ketekunan

Penilaian efficacy menentukan seberapa besar usaha yang dikeluarkan dan seberapa kuat individu bertahan dalam rintangan dan pengalaman yang menyakitkan. Semakin kuat persepsi self-efficacy maka akan semakin giat dan tekun usaha individu ketika menghadapi kesulitan, individu yang mempunyai keraguan tentang kemampuannya akan mengurangi usahanya bahkan individu tersebut akan menyerah. Sedangkan mereka yang memiliki self-efficacy yang kuat, akan menggunakan usaha yang lebih besar untuk mengatasi tantangan. Dengan kata lain, usaha manusia untuk mencapai sesuatu memerlukan perasaan keunggula pribadi (sense of personal efficacy).

c. Pola Berpikir dan Reaksi Emosional

Penilaian individu tentang kemampuannya juga akan mempengaruhi pola berfikir dan reaksi emosional mereka. Individu yang menilai dirinya inefficacy dalam menghadapi tuntutan lingkungan akan mengalami defisiensi personal, dan akan berpikir potensi kesulitan yang lebih besar dari sebenarnya. Akibat dari fikiran tersebut akan menghasilkan reaksi emosional yang tinggi, sepanjang orang percaya mereka dapat mencegah, mengurangi atau mungkin mengakhiri peristiwa yang menyakitkan mereka. Perubahan-perubahan akan jelas dalam intensitas reaksi sebagai fungsi self-efficacy yang berbeda membuktikan, bahwa stres yang berlebihan disebabkan oleh persepsi inefficacy dari tugas-tugas itu sendiri.

\section{Dimensi-dimensi Self-efficacy}

Self-efficacy seseorang sangat bervariasi dalam berbagai dimensi dan berimplikasi dengan kinerja seseorang. Bandura (2006) menyatakan bahwa pengukuran self-efficacy yang dimiliki seseorang mengacu pada tiga dimensi, yaitu:

\section{a. Magnitude/ Level}

Dimensi magnitude/ level berhubungan dengan tingkat kesulitan yang diyakini oleh individu untuk dapat diselesaikan. Misalnya jika seseorang dihadapkan pada masalah atau tugas-tugas yang disusun menurut tingkat kesulitan tertentu maka self-efficacy nya akan jatuh pada tugas-tugas yang mudah, sedang, dan sulit sesuai dengan batas kemampuan yang dirasakan untuk memenuhi tuntutan perilaku yang dibutuhkan bagi masing-masing tingkatnya tersebut.

b. Strength

Dimensi strength berhubungan dengan tingkat kekuatan atau kelemahan keyakinan individu tentang kompetensi yang dipersepsinya. Dengan kata lain, dimensi ini menunjukkan derajat kemantapan seseorang terhadap keyakinannya tentang kesulitan tugas yang bisa dikerjakan. Dimensi ini biasanya berkaitan langsung dengan dimensi magnitude/ level, yaitu makin tinggi taraf kesulitan tugas maka makin lemah keyakinan yang diraskan 
untuk menyelesaikannya. Seseorang dengan self-efficacy yang lemah mudah dikalahkan dengan pengalaman yang sulit. Sedangkan orang yang memiliki self-efficacy yang kuat dalam kompetensi akan mempertahankan usahanya walaupun mengalami kesulitan.

c. Generality

Dimensi generality menunjukkan apakah keyakinan efficacy akan berlangsung dalam domain tertentu atau berlaku dalam berbagai macam aktifitas dan situasi. Dimensi ini berhubungan dengan luas bidang atau tingkat pencapaian keberhasilan seseorang dalam mengatasi atau menyelesaikan masalah atau tugas-tugasnya dalam kondisi tertentu.

Adapun indikator-indikator yang dibuat untuk tugas makalah ini diturunkan dari tiga dimensi yaitu: dimensi Magnitude/level, dimensi Strength, dan dimensi Generality yang diadaptasi dari beberapa penelitian yang sebelumnya dapat dilihat pada tabel berikut:

Tabel 1.

Indikator-Indikator Dimensi Magnitude/Level, Dimensi Strength, dan Dimensi Generality

\begin{tabular}{|c|c|c|}
\hline No. & Dimensi & Indikator \\
\hline 1 & $\begin{array}{l}\text { Magnitudel } \\
\text { Level }\end{array}$ & $\begin{array}{l}\text { 1. Berpandangan optimis dalam mengerjakan pelajaran } \\
\text { dan tugas } \\
\text { 2. Seberapa besar minat terhadap pelajaran dan tugas } \\
\text { 3. Mengembangkan kemampuan dan prestasi } \\
\text { 4. Membuat rencana dalam menyelesaikan tugas } \\
\text { 5. Merasa yakin dapat melakukan dan menyelesaikan } \\
\text { tugas } \\
\text { 6. Melihat tugas yang sulit sebagai suatu tantangan }\end{array}$ \\
\hline 2 & Strength & $\begin{array}{l}\text { 1. Usaha yang dilakukan dapat meningkatkan prestasi } \\
\text { dengan baik. } \\
\text { 2. Komitmen dalam menyelesaikan tugas-tugas yang di } \\
\text { berikan. } \\
\text { 3. Percaya dan mengetahui keunggulan yang dimiliki } \\
\text { 4. Kegigihan dalam menyelesaikan tugas } \\
\text { 5. Memiliki tujuan yang positif dalam melakukan } \\
\text { berbagai hal. }\end{array}$ \\
\hline 3 & Generality & $\begin{array}{l}\text { 1. Menyikapi situasi yang berbeda dengan baik dan } \\
\text { berpikir positif } \\
\text { 2. Menjadikan pengalaman kehidupan sebagai jalan } \\
\text { mencapai kesuksesan } \\
\text { 3. Suka mencari situasi baru } \\
\text { 4. Dapat mengatasi segala situasi dengan efektif } \\
\text { 5. Mencoba tantangan baru }\end{array}$ \\
\hline
\end{tabular}




\section{B. Pembelajaran Berbasis Masalah \\ 1. Definisi Pembelajaran Berbasis Masalah}

Pembelajaran berbasis masalah dalam bahasa Inggris diistilahkan problem based learning pertama kali diperkenalkan pada awal tahun 1970-an sebagai salah satu upaya menemukan solusi dalam diagnosa dengan membuat pertanyaanpertanyaan sesuai situasi yang ada. Duch (2001) mendefinisikan bahwa pembelajaran berbasis masalah merupakan pendekatan pembelajaran yang mempunyai ciri menggunakan masalah nyata sebagai konteks bagi siswa untuk belajar berpikir kritis, keterampilan pemecahan masalah, dan memperoleh pengetahuan mengenai esensi materi pembelajaran.

Mengacu dari pendapat Duch maka pembelajaran berbasis masalah merupakan pembelajaran yang menuntut aktivitas mental siswa secara optimal dalam belajar berpikir kritis, keterampilan pemecahan masalah, dan memperoleh pengetahuan mengenai esensi dari materi pelajaran dalam memahami suatu konsep, prinsip, dan keterampilan matematis siswa berbentuk ill-stucture atau open-ended melalui stimulus.

Menurut Suradijono, PBL adalah metode belajar yang menggunakan masalah sebagai langkah awal dalam mengumpulkan dan mengintegrasikan pengetahuan baru (Krismiati, 2008). Atau menurut Boud \& Felleti (dalam Krismiati, 2008) menyatakan bahwa Problem based learning is a way of constructing and teaching course using problem as a stimulus and focus on student activity.

\section{Karakteristik dan Ciri Pembelajaran Berbasis Masalah}

Pembelajaran berbasis masalah memiliki sepuluh karakteristik utama yang harus dipenuhi sebagaimana yang dikemukakan oleh Amir (2009) yaitu: sebagai berikut:

a. permasalahan menjadi starting point dalam belajar;

b. permasalahan yang diangkat adalah permasalahan yang ada di dunia nyata yang tidak terstruktur;

c. permasalahan membutuhkan perspektif ganda (multi perspective);

d. permasalahan menantang pengetahuan yang dimiliki oleh siswa sikap dan kompetensi yang kemudian membutuhkan identifikasi kebutuhan belajar dan bidang baru dalam belajar;

e. belajar pengarahan diri menjadi hal yang utama;

f. pemanfaatan sumber pengetahuan yang beragam penggunaannya dan evaluasi sumber informasi merupakan proses yang esensial dalam PBM;

g. belajar adalah kolaboratif, komunikasi, kooperatif;

h. pengembangan keterampilan inkuiri dan pemecahan masalah sama pentingnya dengan penguasaan isi pengetahuan untuk mencari solusi dari sebuah permasalahan;

i. keterbukaan proses dalam PBM meliputi sintesis dan integrasi dari sebuah proses belajar;

j. PBM melibatkan evaluasi dan review pengalaman dan proses belajar. 
Barrett (2005 : 15) merumuskan ciri PBL sebagai berikut:

a. Mula-mula masalah diberikan kepada siswa.

b. Siswa mendiskusikan masalah itu dalam kelompok. Mereka mengklarifikasi fakta, mendefinisikan apa masalahnya. Menggali gagasan berdasarkan pengetahuan sebelumnya. Menemu-kenali apa yang mesti diketahui (dipelajari) untuk memecahkan masalah itu (isu belajar terletak di sini). Bernalar melalui masalah dan menentukan apa tindakan atas masalah tersebut.

c. Setiap siswa secara perorangan aktif terlibat mempelajari pengetahuan yang diperlukan untuk menyelesaikan masalah mereka.

d. Bekerja kembali berkelompok untuk menyelesaikan masalah

e. Menyajikan selesaian atas masalah

f. Melihat dan menilai kembali apa yang telah mereka pelajari dari pengalaman memecahkan masalah itu.

Menurut Barrett, agar berhasil, seorang fasilitator yang menggunakan PBL sebagai pendekatan pembelajaran mestilah:

a. Tertarik dan antusias

b. Melupakan ceramah

c. Menenggang keheningan

d. Membuat siswa berinteraksi satu sama lain

e. Mendorong penggunaan sumber informasi akurat sewaktu siswa menyelidiki isu belajarnya

f. Berorientasi sasaran masalah dan belajar

g. Menciptakan lingkungan belajar yang mendukung untuk kelompok belajar

\section{Langkah-langkah Pembelajaran Berbasis Masalah}

Ada 5 langkah dalam pembelajaran berbasis masalah dan perilaku yang dibutuhkan oleh guru seperti yang dikemukakan oleh Ibrahim dkk (dalam Rusman, 2012) yang disajikan tabel berikut:

\section{Tabel 2. Langkah-langkah Pembelajaran Berbasis Masalah}

\begin{tabular}{|c|l|l|}
\hline Fase & \multicolumn{1}{|c|}{ Indikator } & \multicolumn{1}{|c|}{ Tingkah Laku Guru } \\
\hline $\mathbf{( 1 )}$ & \multicolumn{1}{|c|}{$(\mathbf{2})$} & \multicolumn{1}{|c|}{$\mathbf{( 3 )}$} \\
\hline 1 & $\begin{array}{l}\text { Orientasi siswa pada } \\
\text { masalah }\end{array}$ & $\begin{array}{l}\text { Menjelaskan tujuan pembelajaran, menjelaskan } \\
\text { logistik yang diperlukan, dan memotivasi siswa } \\
\text { terlibat pada aktivitas pemecahan masalah }\end{array}$ \\
\hline 2 & $\begin{array}{l}\text { Mengorganisasikan } \\
\text { siswa untuk belajar }\end{array}$ & $\begin{array}{l}\text { Membantu siswa mendefinisikan dan } \\
\text { mengorganisasikan tugas belajar yang } \\
\text { berhubungan dengan masalah tersebut }\end{array}$ \\
\hline 3 & $\begin{array}{l}\text { Membimbing } \\
\text { pengalaman } \\
\text { individual/kelompok }\end{array}$ & $\begin{array}{l}\text { Mendorong siswa untuk mengumpulkan } \\
\text { informasi yang sesuai, melaksanakan } \\
\text { eksperimen untuk mendapatkan penjelasan dan } \\
\text { pemecahan masalah }\end{array}$ \\
\hline
\end{tabular}




\begin{tabular}{|c|l|l|}
\hline (1) & \multicolumn{1}{|c|}{ (2) } & \multicolumn{1}{|c|}{ (3) } \\
\hline 4 & $\begin{array}{l}\text { Mengembangkan } \\
\text { dan menyajikan hasil } \\
\text { karya }\end{array}$ & $\begin{array}{l}\text { Membantu siswa dalam merencanakan dan } \\
\text { menyiapkan karya yang sesuai seperti laporan, } \\
\text { dan membantu mereka untuk berbagi tugas } \\
\text { dengan temannya }\end{array}$ \\
\hline 5 & $\begin{array}{l}\text { Menganalisis dan } \\
\text { mengevaluasi proses } \\
\text { pemecahan masalah }\end{array}$ & $\begin{array}{l}\text { Membantu siswa untuk melakukan refleksi atau } \\
\text { evaluasi terhadap penyelidikan mereka dan } \\
\text { proses yang mereka gunakan }\end{array}$ \\
\hline
\end{tabular}

Dari tabel 2, dapat dilihat bahwa guru mengawali pembelajaran dengan menjelaskan tujuan yang hendak dicapai dalam pembelajaran, mendeskripsikan, dan memotivasi siswa untuk terlibat dalam aktivitas dalam kegiatan mengatasi masalah. Berdasarkan masalah yang dipelajari, siswa berusaha untuk membuat rancangan, proses, penelitian yang mengarah ke penyelesaian masalah, sehingga membangun pengetahuan mereka sendiri melalui pengalaman nyata, kemudian siswa mengidentifikasi permasalahan dengan cara mencari apa saja hal-hal yang diketahui, yang ditanyakan, dan mencari cara yang cocok untuk menyelesaikan permasalahan tersebut. Dalam menginvestigasikan dan menyelesaikan masalah, dalam prosesnya siswa menggunakan banyak keterampilan sehingga termotivasi untuk memecahkan masalah nyata dan guru mengapresiasi aktivitas siswa sehingga siswa senang bekerja sama.

Menurut Forgarty (Rusman, 2012) langkah-langkah yang akan dilalui oleh siswa dalam sebuah proses PBL/PBM adalah sebagai berikut:
a. menemukan masalah;
b. mendefinisikan masalah;
c. mengumpulkan fakta;
d. menyusun hipotesis;
e. melakukan penyelidikan;
f. menyempurnakan masalah yang telah didefinisikan;
g. menyimpulkan alternatif pemecahan secara kolaboratif; dan
h. melakukan pengujian hasil solusi pemecahan masalah. 


\section{Kaitan Pembelajaran Berbasis Masalah dengan Kemampuan Self- Efficacy Siswa}

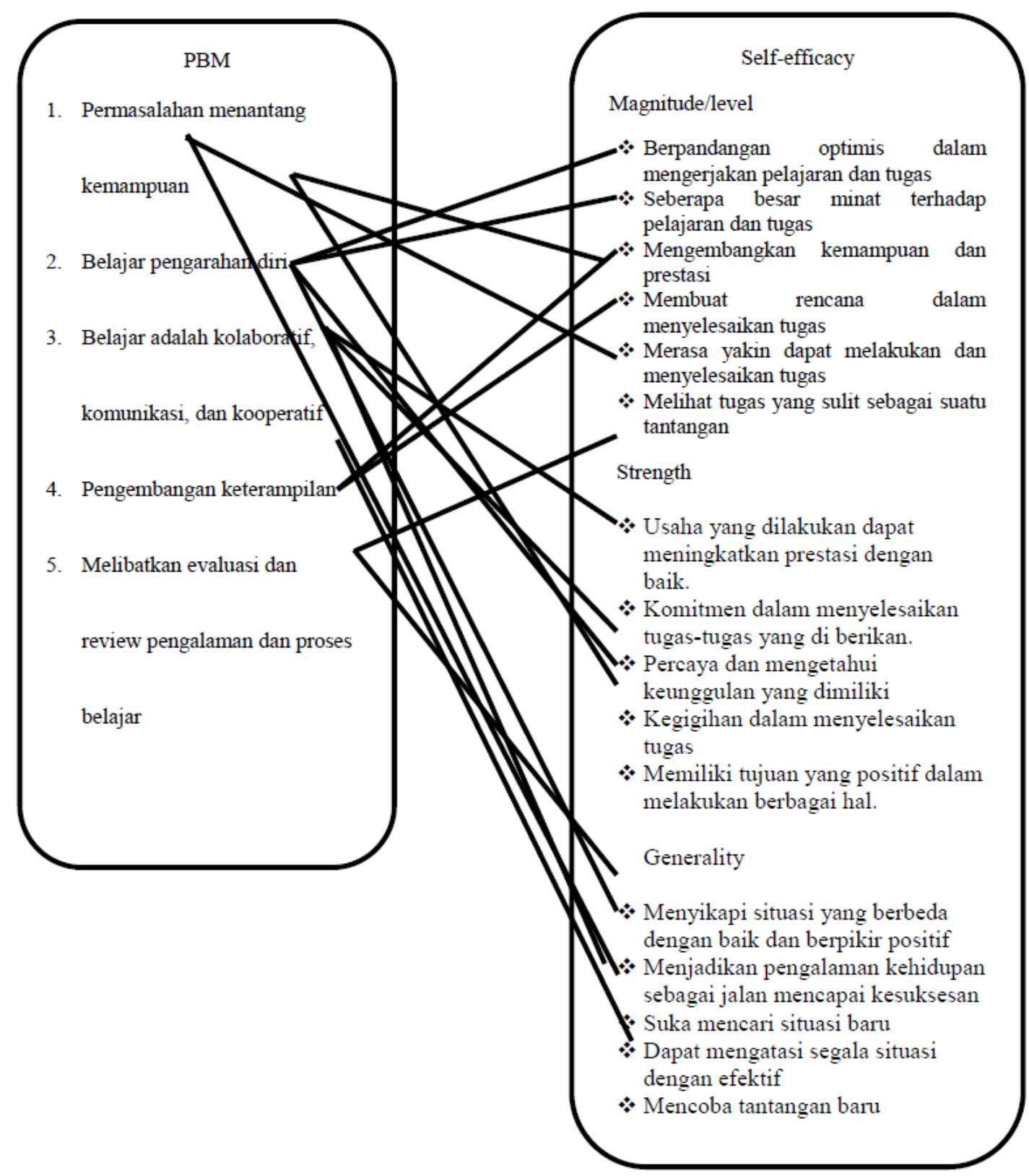

DAFTAR PUSTAKA

Amir, M.T. (2009). Inovasi Pendidikan Melalui Problem Based learning. Jakarta: Kencana Prenada Media Group.

Bandura, A. (2006). Guide for Constructing Self-efficacy Scales, Self-efficacy Beliefs of Adolescents, pp. 307-337. [Online]. Tersedia http://www.des.emory.edu/mfp/014-BanduraGuide2006.pdf 
Barrett, T et al., (2005). Handbook of Enquiry \& Problem Based Learning. Barrett, T., Mac Labhrainn, I., Fallon, H. (Eds). Galway: CELT. [Online]. Tersedia http://www.nuigalway.ie/celt/pblbook [1 Juni 2013].

Dewanto, S. P. (2007). Meningkatakan Kemampuan Representasi Multipel Matematis Mahasiswa Melalui Belajar Berbasis Masalah. Disertasi. UPI: Tidak diterbitkan.

Duch, B.J., Groh, S.E., dan Allen, D.E. (2001). Why Problem-Based Learning: A Case Study of Institutional Change in Undergraduate Education. Dalam B.J. Duch, S.E. Groh, dan D.E. Allen (Eds): The Power of Problem-Based Learning. Virginia, Amerika: Stylus Publishing.

Krismiati, A. (2008). Pembelajaran berbasis masalah berbantuan Cabry II dalam meningkatkan kemampuan pemecahan dan berpikir kritis siswa. Tesis UPI Bandung: Tidak diterbitkan.

Rusman. 2012. Model-Model Pembelajaran Mengembangkan Profesionalisme Guru. Jakarta: RajaGrafindo Persada.

Sudrajat, D. (2008). Program Pengembangan Self-efficacy Bagi Konselor di SMA Negeri Se-Kota Bandung. Tesis. UPI: Tidak diterbitkan.

Widyastuti. (2010). Pengaruh Pembelajaran Model-Eliciting Activities terhadap Kemampuan Representasi Matematis dan Self-Efficacy Siswa. Tesis. UPI: Tidak ditebitkan. 